\title{
Social media y libros 2.0
}

\author{
Pedro Palao Pons \\ Creador de +APD (Más allá del Papel - Libros 2.0) \\ Servicios integrales de comunicación
}

Que el libro tradicional y la forma de elaborarlo y promocionarlo, tienen los días contados, es un hecho. Que a corto y medio plazo vamos a ver una revolución en Internet, también.

Hace unos años, pocos, que un autor tuviera una página web parecía un canto al ego, hoy es imprescindible. Pero en el sector editorial las cosas cambian a velocidad de vértigo. Lo importante ahora no es que el autor esté en Internet, lo trascendente es que interactúe con sus lectores. Atrás queda el escritor, sea ensayista o novelista, que vivía apartado del mundo en su particular burbuja creativa. Un micromundo del que salía, excepcionalmente, para presentar su libro o firmar unos ejemplares en fechas señaladas. Hoy la firma de libros se efectúa, cada vez más, a modo virtual a través de las redes sociales y el garabato tras la dedicatoria, no es sino una anécdota. Antes un ejemplar firmado significaba que en algún momento autor y lector habían estado cara a cara, fugazmente, tal vez compartiendo unos minutos de charla. Actualmente las redes sociales permiten ver al autor, compartir e interactuar con él hasta el punto de comentarle su obra página a página. Hoy, como ayer la personal webpage, Twitter o Facebook son imprescindibles para el autor como para el editor. Ayer se acordaban encuentros en conferencias de presentación. En la actualidad el encuentro es directo y simultaneo, sin desplazamiento y gracias, por ejemplo, a una video conferencia online. Pero debemos ir un paso más allá.

Los autores tendrán, tienen ya que aceptar — todavía los hay muy reticentes-, que no están solos. Se deben a sus lectores, a sus comentarios y exigencias online. Ese es el poder del social media. Y lo mismo acontece con los editores 
que, en la redes sociales globalizadoras, tienen una oportunidad de oro, todavía un tanto desaprovechada y a veces una pizca temida.

Las nuevas tecnologías y mercados de social media exigen renovados métodos e innovadores productos. Un libro no puede terminar en la contraportada. Ahora, las historias y tramas de las novelas o los estudios y datos de los ensayos cobran nueva vida en la red. Se prolongan y expanden, rompiendo las fronteras de sus predecesores, gracias a las redes sociales, a contenidos interactivos, a spots virales que han convertido el antiguo boca-oreja en un pantalla-pantalla. La empresa o el escritor que no sepa, no pueda o no quiera asumir eso, tiene un problema.

El libro, sea en papel o digital, debe conquistar un nuevo público: el lector que ha nacido y crecido en la sociedad visual y digital. Debe dotarse de nuevos contenidos interactivos. Ese es uno de los objetivos de las nuevas empresas de comunicación del sector, que contemplan el libro 2.0 como una herramienta infinita, visual, ágil y social. Un instrumento con capacidad de renovarse, e incluso - en algunos casos - de ser escrito al tiempo por autor y lector. Atrás queda la fotografía de cubierta en PDF con su nota de prensa al uso, como sistema de promoción. Es tiempo del booktrailer, es momento de sintetizar con espectaculares imágenes, banda sonora y textos sugestivos, el contenido de un libro en un video que terminará expuesto en la página web del autor, de la editorial y que llegará a los medios de comunicación y a los perfiles sociales de miles de personas. Ahí está la auténtica promoción directa y el verdadero reto de futuro en comunicación social: saber gestionar adecuadamente esas herramientas que hoy sólo comenzamos a intuir.

\section{Referencia de este artículo:}

Palao Pons, Pedro (2012). Social media y libros 2.0. En: adComunica. Revista Científica de Estrategias, Tendencias e Innovación en Comunicación, $\mathrm{n}^{\circ} 3$. Castellón: Asociación para el Desarrollo de la Comunicación adComunica, Universidad Complutense de Madrid y Universitat Jaume I, 215-216. DOI: http://dx.doi. org/10.6035/2174-0992.2012.3.14 